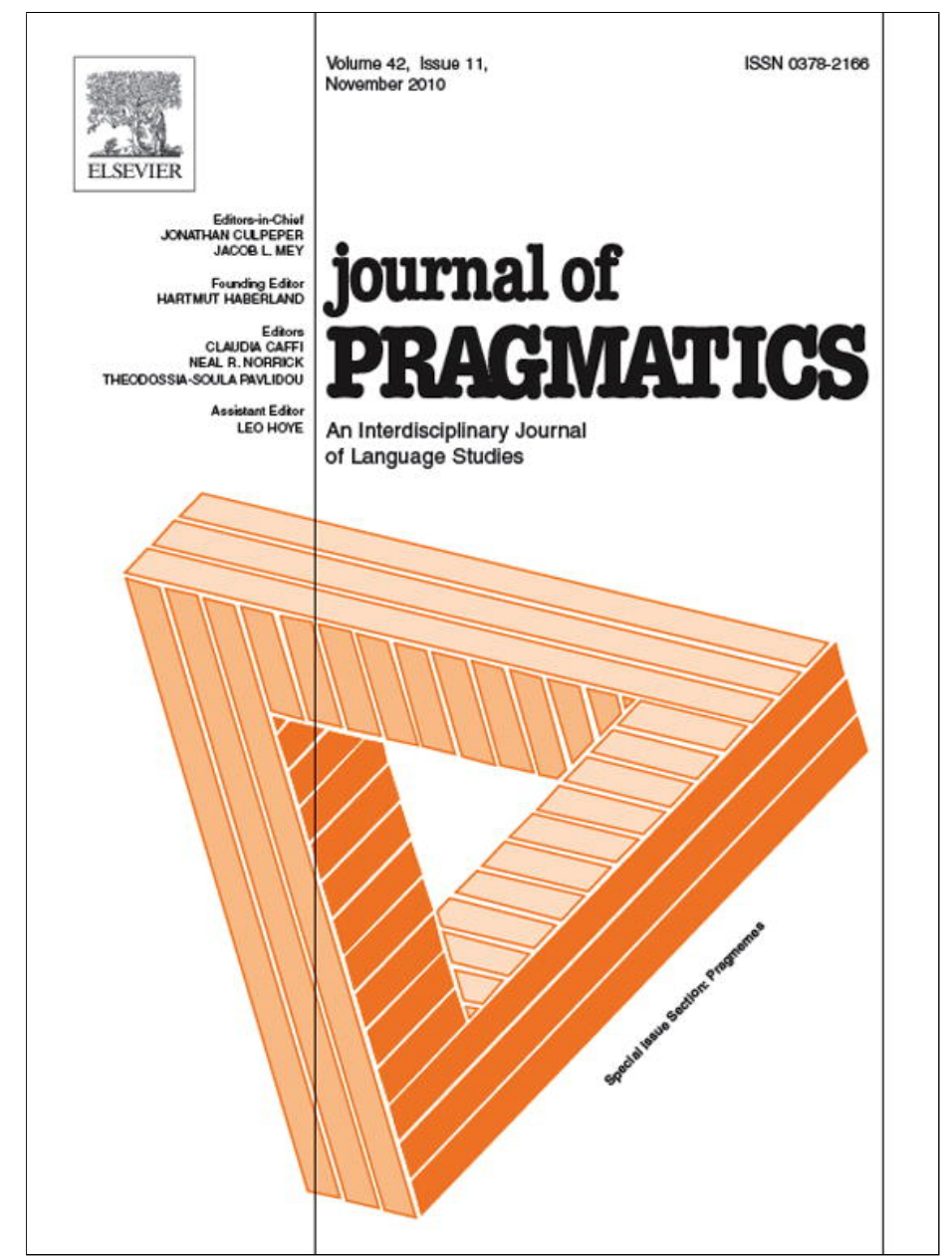

This article appeared in a journal published by Elsevier. The attached copy is furnished to the author for internal non-commercial research and education use, including for instruction at the authors institution and sharing with colleagues.

Other uses, including reproduction and distribution, or selling or licensing copies, or posting to personal, institutional or third party websites are prohibited.

In most cases authors are permitted to post their version of the article (e.g. in Word or Tex form) to their personal website or institutional repository. Authors requiring further information regarding Elsevier's archiving and manuscript policies are encouraged to visit:

http://www.elsevier.com/copyright 


\title{
Barack Obama's South Carolina speech ${ }^{\text {th }}$
}

\author{
Alessandro Capone \\ Department of Philosophy, University of Palermo, Via San Francesco P 105, 98051 Barcellona PG ME, Italy
}

\section{A R T I C L E I N F O}

\section{Article history:}

Received 27 April 2010

Accepted 10 June 2010

\section{Keywords:}

Pragmemes

Barack Obama

Personification

Speech

\begin{abstract}
A B S T R A C T
In this paper, I shall analyze US Presidential Barack Obama's South Carolina victory speech from the perspective of pragmemes. In particular, I shall explore the idea that this speech is constituted by many voices (in other words, it displays polyphony, to use an idea due to Bakhtin, 1981, 1986) and that the audience is part of this speech event, adding and contributing to its text in a collaborative way (in particular, in constructing meaning). As many are aware (including the journalists who report day by day on Barack Obama's achievements), Obama uses the technique of 'personification'1 (The Economist, December 13th, 2007). When he voices an idea, he does not just expose it as if it came from himself, but gets another person (fictitious or, plausibly, real) to voice it. Since in an electoral speech, he cannot reasonably get people on stage to voice his ideas, he personifies ideas by narrating what people told him. His stories are his way of personifying his ideas. The discourse strategy he uses serves to reverse the direction of influence from the people in control to the people controlled (see Van Dijk, 2003).

In this paper, I also argue that Barack Obama's speech contains echoes of Martin Luther King Jr's 'I have a dream speech' and that its structure is best understood in the light of Afro-American sermons. I explain analogies and disanalogies.
\end{abstract}

(c) 2010 Elsevier B.V. All rights reserved.

\section{Introduction}

This paper connects with my work on pragmemes (Capone, 2005), based, in turn, on Mey's work (Mey, 2001). As Mey says:

Speech acts, in order to be effective, have to be situated. That is to say, they both rely on, and actively create, the situation in which they are realized. Thus, a situated speech act comes close to what has been called a speech event in ethnographic and anthropological studies (Bauman and Sherzer, 1974): speech as centred on an institutionalized social activity of a certain kind, such as teaching, visiting a doctor's office, participating in a tea-ceremony, and so on. In all such activities, speech is, in a way, prescribed: only certain utterances can be expected and will thus be acceptable; conversely, the participants in the situation, by their acceptance of their own and others' utterances, establish and reaffirm the social situation in which the utterances are uttered and in which they find themselves as utterers (Mey, 2001, 219).

Pragmemes are speech acts whose effects obtain through the use of language as situated in culture. I have outlined the theory of pragmemes in the Introduction to this special issue. In particular, I have stressed the connection between the theory of pragmemes and Hyme's notion of communicative competence and Dennett's (1991) theory of memes - concepts which can

\footnotetext{
I would like to express my thanks to Dan Sperber, Jacob Mey, Neal Norrick, Sarah Blackwell and Alessandro Duranti for their encouragement and advice. I would also like to thank Nicola Owtram for his very detailed comments. I am grateful to Ira Noveck, who helped with the transcription. E-mail address: alessandro.capone@istruzione.it.

${ }^{1}$ Personification is an ontological metaphor in which a thing or abstraction is represented as a person.
} 
be propagated by cultural transmission, contrasting them to Chomsky's theory according to which language is biologically determined in our DNA. In the introduction I have also addressed the issue of intentionality and that of cancellability. Intentionality is a mental phenomenon: it is usually a mental cause that prompts either linguistic or nonlinguistic actions. Linguistic intentionality is what animates a speech act: it is the reason why the speech act is proffered as well as the intended consequence of the speech act. If all goes well, and the speaker's communicative purpose is understood properly, the addressee will fulfil that purpose. 'Intention' originally meant 'aiming at'. So, it is reasonable that an utterance should aim at something (its purpose) and be fulfilled if the purpose is taken up. Whether pragmemes are cancellable or not is a deep question, which cannot be resolved here. However, I maintain that in a number of cases pragmemes are non-cancellable aspects of meaning. In my previous work on pragmemes, including the Introduction, I dealt with illocutionary force, but it should be said that pragmemes may involve more than that. While Mey specifically deals with speech act force and claims that this is a function of context (he calls the speech act in context 'pragmeme'), I deal with the issue of the speaker's/author's intentionality and I address the question: whose voice is the one expressed in a speech act? I propose that Mey's notion of the pragmeme must encompass not only illocutionary force but also intentionality, as well as the phenomenon of voicing (see Capone, forthcoming). I do all this by analysing a speech by Barack Obama. In my paper on pragmemes (Capone, 2005), I dealt with inferential augmentations occurring due to societal norms of utterance interpretation. Presumably those inferences were of a non-cancellable type. In this paper, I argue that an important type of inference is the one concerning responsibility for the utterance. Who is the author/ principal of the utterance? (The notion of responsibility mainly covers both content and style. The person who is responsible for an utterance is the person who worked out the content of the utterance and (also, usually) put it into a linguistic shape. Normally, this person is associated with the person who animates a speech. But it can be dissociated, as in the case of ambassadors. Responsibility is associated with bearing the consequences of the action). In the text I shall examine in this paper, I shall focus on the attribution of responsibility/intentionality on the basis of rich features of the context of utterance and of the social norms operative in that context. I argue that the political speech is of paramount importance in attributing intentionality as belonging to both the speaker and the audience and that an important rhetorical strategy is to maximize such possible attributions.

The structure of the paper is as follows. First of all, I expose the methodology utilized in the paper, after that I discuss the context of the speech event, then I outline the content of the paper, subsequently I move on to the analysis of the data and to the discussion. I sum the key notions in the conclusion. The transcription of the speech is provided in Appendix 1. In Appendix 2 I expand the discussion of the echoes of Martin Luther King Jr.

\section{Methodology}

In this paper I analyse Barack Obama's South Carolina speech with a view to contextualize this speech event and analyse it in an intertextual way. The main idea is that we should analyse what is said by Obama by reference to what other people said. The aim of the paper is to draw a number of theoretical conclusions on the basis of the discussion of the data, mainly in relation to the notion of footing, as revisited by Duranti and Goodwin. A lot of attention will be devoted to the transcription, since it will furnish us theoretical tools for understanding the relationship between Obama and the audience, which is one of animator/principal. I propose to devote serious attention to pauses and to the predictive power of intonation, lengthening and softening of speech. The transcription of the speech and the transcription symbols are in Appendix 1. The text has been numbered to facilitate understanding of the analysis. The method I used in extracting theoretical considerations was to start with a theoretical framework (Goffman's notion of footing connected with Bakhtin's notion of polyphony), to see how that framework could be applied to the text analysed, and then move on to theoretical considerations which modify the framework by connecting it to the framework of the ethnography of communication.

\section{The context (the historical and cultural background)}

It is important to provide information about the historical and cultural context in which the speech is situated. This will help readers understand the speech.

\subsection{The historical context}

The speech occurs in January 2008, a period of financial crisis for America and its economic partners, such as Europe. This is a period in which America has accumulated an enormous public debt (not to mention the individual Americans' negative bank balances) and in which some economists (e.g. Loren Goldner) have made dire predictions about the future. Such predictions have partially turned out to be true, witness the recent partial stock exchange collapse (due to the sub-prime mortgage crisis, fear of economic recession, and the persistent weakening of the US dollar). In addition to the economic crisis (partly due to the USA's misguided involvement in the Iraq war), USA's prestige has suffered enormously from revelations that the CIA had fabricated evidence of a (military) nuclear build-up in Iraq, as well as from the failure of the military campaign in Iraq itself, where the local government is hardly capable of resisting military attacks from hostile forces inside the nation (fomented by Al Qaeda). Even if Europeans may be partially unaware of America's situation at the moment, the situation was brought out into the open by a series of financial disasters which affected the financial world - especially banks 
and companies specializing in mortgages. These events are hinted at by Obama's speech. Barack Obama presents himself as the person who brings change and who promises to deliver the changes forecast by Martin Luther King Jr. Barack Obama's speech, therefore, cannot lack echoes of Martin Luther King Jr's words. These words, too, are embedded in some kind of main speech.

\subsection{The cultural context}

Now that we have sketched the historical context, a few words will suffice to sketch the cultural context. Electoral speeches are public settings where audiences can respond to some of the things said by a speaker. Of course, audiences are restricted in what they may do in response to what a speaker says, being for the most part confined to the production of displays of affiliation (e.g. applause, cheers, and laughter) or disaffiliation (e.g. by booing or jeering). These displays, as Atkinson (1984) says, involve simultaneous, coordinated activities by a group of people and have the characteristic that they can be done together (for example, applause is an activity that can be done effectively by a number of people). If audiences were not restricted in their production of (visible or audible) displays of affiliation/disaffiliation, one easily imagines the sort of chaos that would characterize public meetings. According to Atkinson (1984), there are conventions for orderly participation by the audience in such meetings; he points out that in his transcriptions, one could notice that the audience's response often occurs slightly before or immediately after the end of the last sentence. This induces the analyst to conclude that there must be techniques for anticipating/projecting pauses at turn transition. Atkinson claims that names, lists of things, contrasts, and self-praise or other-criticism are techniques which prompt audience affiliation (in addition to other prosodic techniques, such as a marked difference in volume, downward shifts in intonation, etc.).

More should be said about the influence of Afro-American sermons on Obama's speech. I postpone the detailed analysis of Obama's speech in terms of this influence to a section in which I argue, following Duranti (1991), that a portion of speech may contain more than one voice, and that Afro-American sermons are a type of speech event where the intense participation of the audience involves exactly the kind of phenomenon discussed by Duranti and exemplified by Obama's speech. For the time being, I refer to Davis (1987), who provides a detailed description of the overall structure of the African American sermon as a narrative event. He identifies five major components of traditional Black sermons: (i) preacher tells the congregation that the AMEN AND HALLELUJAH PREACHING sermon was provided by God; (ii) preacher identifies the theme, followed by a Bible quotation; (iii) preacher interprets the scripture literally and then broadly; (iv) each unit of the sermon contains a secular-versus-sacred conflict and moves between concrete and abstract; ( $v$ ) closure is absent, and the sermon is left open-ended.

In general, it appears that Barack Obama makes the most of the characteristics of black styles for rhetorical purposes (see Kochman, 1981). While in this short paper I cannot do justice to the long list of differences between English white and black styles, a few differences seem to be of relevance to the discussion at hand. Blacks are more likely to take the orator's stance of passionate involvement and argument with the adversary; for them confrontation signifies caring about something; they require responses on the part of the addressee; they may agitate to increase the level of emotional intensity and response. It is intuitively clear that (sustained) genuine emotion in Barack Obama's speech serves to project the impression that he cares about the USA's destiny.

\section{Content}

Before proceeding to the analysis of the speech event in question, I want to dwell on the key notions I will discuss.

\subsection{On polyphony}

In this paper, I shall analyze US Presidential Barack Obama's South Carolina victory speech from a particular pragmatic perspective. In particular, I shall explore the idea that this speech is constituted by many voices (in other words, it displays polyphony, to use an idea due to Bakhtin $\left.{ }^{2}, 1981,1986\right)$ and that the audience is part of this speech event, adding and contributing to its text in a collaborative way (in particular, in constructing meaning).

As many are aware (including the journalists who report day by day on Barack Obama's achievements), Obama uses the technique of 'personification' (The Economist, December 13th, 2007). When he voices an idea, he does not just expose it as if it came from himself, but gets another person (fictitious or, plausibly, real) to voice it. Since, in an electoral speech, he cannot reasonably get people on stage to voice his ideas, he personifies ideas by narrating what people told him. His stories are his

\footnotetext{
${ }^{2}$ To simplistically reduce polyphony to a multiplicity of voices, of course, is to oversimplify things. For Bakhtin, a person is always changing and there are different manifestations of the same person. Furthermore, a person can change as a result of what other people think or say of him. Polyphony is related to Bakhtin's notion of unfinalizability. As to the concept of the unfinalizable self, individual people cannot be finalized, completely understood, known, or labeled. Though it is possible to understand people and to treat them as if they are completely known, Bakhtin's conception of unfinalizability respects the possibility that a person can change, and that a person is never fully revealed or fully known in the world. The notion of a multiplicity of voices is connected with the idea that reality is changeable, since a person is influenced by other people's attitudes to her. Poyphony is also related to truth. Polyphonic truth requires the representations of more than one voice.
} 
way of personifying his ideas. The discourse strategy he uses serves to reverse the direction of influence from the people in control to the people controlled (see Van Dijk, 2003). ${ }^{3}$

\subsection{On footing}

I want to formulate explicitly what I have said so far in the terminology proposed by Goffman in his work on 'footing'. ${ }^{4}$ According to Goffman, one can distinguish various roles in relation to what a person says in her utterance. As an animator of discourse, a speaker simply reads and recites a script that she need not have created. As an author, a speaker both composes and utters the words she speaks. As a principal, a speaker is responsible for the positions or opinions advanced, but need not necessarily be the animator or even the author. In fact, the principal can sometimes be a social institution. As Goffman says:

When one uses the term "speaker", one often implies that the individual who animates is formulating his own text and staking out his own position through it: animator, author, and principal are one (2007: 397).

\section{Goffman also writes:}

Sometimes one has in mind that "a principal" (in the legalistic sense) is involved, whose beliefs have been told, someone who is committed to what the words say. Note that one deals in this case not so much with a body or mind as with a person, active in some particular social identity or role, some special capacity as a member of a group, office, category, relationship, association, or whatever, some socially based source of self-identification. Often this will mean that the individual speaks, explicitly or implicitly, in the name of "we", not "I" (...) the "we" including more than the self (Goffman, 2007).

My initial suggestion that in the case of an electoral speech, it is the audience that in part establishes the meaning of what is said, and that the speaker's intention somehow coincides with that of the audience, is confirmed by what Goffman says about the main speaker being both the animator (the sounding box) and the author/principal of his speech. In the same vein, still in accordance with Goffman, the audience could very well be the "principal" in the sense that the main speaker speaks on its behalf; that is, the speaker speaks in the name of "we", not "I". After all, to win an election a speaker must become the representative of a community of people (an aggregate of social groups), and to become such a representative one must show/prove that one's voice is the voice of the nation, or at least expresses the voice(s) of the nation. This is at the heart of Barack Obama's argumentative strategy. The structure of his speech proves that he has a right to become a representative of the people, the people's president, as he is able to express the various voices which constitute the people (to speak with the words of the people, adopting their styles).

Above, I have utilized Goffman's notions (as introduced in the 'footing' article; 2007) to overcome some of the defects an author such as Goodwin finds there. According to Goodwin (2007), in Goffman's conceptualization of 'footing', speakers and hearers inhabit separate worlds, with quite different frameworks being used for the analysis of each; this makes it difficult to build a model in which different kinds of participants act in concert. In contrast, my analysis brings out how the speaker and the hearer can perform concerted actions together.

\subsection{Connecting polyphony and footing}

One may wonder about the connection between polyphony and footing. Surely there is a connection, since every time a speaker wants to express the voice of another, she has a technique available: 'quoting', that is to say acting as an animator. Of course, quoting is not the only device that can be used to express other people's voices. One can use stories and, since stories have as part of their structure an evaluative unit, it goes without saying that the evaluative part must be attributed either to the character of the story or to the narrator. In the case in point, the narrator (Barack Obama) identifies with the characters of the story and thus the evaluative parts can be seen as coming from the characters' lips. When stories and their evaluative units are injected into the narration, the devices of polyphony and footing merge, as a character's voice is seen as associated with an evaluation and this evaluation is seen as coming from the character's voice, not only from the narrator's voice. Which voice belongs to whom can be determined through inference, and this is the reason why footing is involved in the first place, since footing is based on inferences as to who is the animator, who is the author and who is the principal (Capone, forthcoming). These inferences need to be situated. In the present paper, I, therefore, cast my observations in the framework of what is usually called "ethnography of communication" (Hymes, 1964). The focus of analysis of Hymes and his associates

\footnotetext{
${ }^{3}$ Duranti (2006b) writes that the language of politics has been presented and studied in terms of its ability to persuade an audience (of peers, subjects, and superiors) to go along with the speaker's view of the world and his or her proposal (Perrot, 2000). In much of this literature, the successful political leader is seen as a skilful manipulator who controls a variety of linguistic resources - from elaborate metaphors to paralinguistic features like volume, intonation, and rhythm - through which listeners can be convinced to accept a course of action (including the action of voting for the speaker). (Duranti, 2006b, 467)

4 'Footing' refers to the various representations of participation roles. Is a person participating as (mere) animator, as author, or as principal? An animator simply voices a speech but does not take responsibility for that. The author is involved in writing the speech, but need not take responsibility for that. The principal usually takes responsibility for his words. A speaker is, by default, animator, author and principal (Capone, forthcoming) unless there are heavy contextual clues that prevent this inference from arising.
} 
is the speech act (the actual speech act) that occurs in a context (the context is understood both as the set of events that surround the actual event, as well as the set of cultural norms in which it is embedded). A communicative event is to be considered as embedded in culture; thus, the analysis cannot fail to take into consideration crucial information that makes up the culture in which the speech act occurs. Hymes is mostly interested in describing 'communicative competence', in other words in defining the kinds of behaviour that are acceptable in a certain speech event, embedded in a given culture for the participants in the event in question. As Bauman and Sherzer (1974) and Mey (2001) say, speech as centred on an institutionalized social activity of a certain kind is, in a way, prescribed: only certain utterances are expected and will, thus, be acceptable. In the present paper, I follow Hymes in the way he focuses on the culture in which the speech event is immersed, the situation which elicited the communicative event, the form of the message (its rhetorical structure), the participation framework (which, I argue, is interconnected with the issue of form), and the oral channel (the oral medium).

\section{Analysis}

In this section I provide analytic considerations on the text investigated, in which I put to work notions like polyphony and footing.

\subsection{Collaborative strategies}

Pre-planned though it may be (it is clear, from the comparison with other speeches by Barack Obama and other electoral speeches, that many segments are recycled from previous speeches and recited by heart), the text is, after all, the result of a collaboration between the main speaker (Obama) and the secondary speakers (the audience). It may be the case that the segments of speech attributed to the audience are also pre-planned, being elicited by the organizers of the campaign who have mixed in with the audience. However, the choral character of the audience's responses attests that, although these segments of speech may have been artificially induced (and thus may not be completely spontaneous), they have a deep resonance in the audience's sentiment. The only points at which the audience's reactions are weaker are those in which Barack Obama talks about the sacrifices involved; this seems to attest to the naturalness and instinctiveness of the audience's responses, which come from the heart and not just from following a script and responding to prompts from Obama's collaborators who suggest what to say (see Wharry, 2003).

Interestingly, in other speeches by Obama (transcribed for the benefit of the people visiting Obama's homepage), the audience's contribution is only minimally acknowledged by sentences such as 'people chanting' or 'people cheering'. However, if we watch the video, we can register the audience's verbal reaction as utterances proffered chorally (often in the way of chanting), such as: "Yes we can”, “We can change”, “Yeah”, “No", “Right”, etc. The length of the audience's responses varies, but it appears that there is a perfect synchrony between the speaker and the audience, as the audience is able to distinguish short from long pauses and does not disturb or disrupt the main speaker's words. To transform short pauses into long pauses would inevitably affect comprehension, as it would prevent the speaker's sentences from being articulated in their syntactic complexity.

\subsection{Long pauses}

Long pauses are recognizably places which do not disrupt comprehension and syntactic articulation - they are recognized as places that the speaker wants the audience to recognize as such, and as places appropriate for long pauses and animated reactions. But what devices does the speaker employ for signalling the length of an intended pause? Presumably, a long pause may give rise to a long period of chanting, cheering, etc., but it is not sufficient on its own to project the speaker's intention. Instead, we need to find out whether there is a way for the audience to predict what is intended by the speaker to be recognised as a long pause. Tannen's (2007) suggestion that slower and softer speech is predictive of long pauses seems to be borne out by my annotation of this speech event. And if it is true that slower speech and softer speech are predictive devices, the text must be seen as a collaborative enterprise in which the audience is in some ways used by the main speaker to voice a kind of theatrical speech - the audience is used as a choral dramatis persona. But to be so used, there must be some instinctive collaborative spirit in the speech event, something which a speaker cannot impose, but only obtain by commanding respect.

\subsection{Vagueness and co-construction of meaning}

Another point I would like to make is that the main speaker's speech acts are meant to be interpreted, not by following the speaker's univocal intention, ${ }^{5}$ but by participating in a process through which the audience's intentionality accrues to the main speaker's intentionality (meaning is being collaboratively created). There are two ways in which this process can happen: on the one hand, a political speech is in itself an interpretation of the audience's feelings and needs, and is meant to

\footnotetext{
${ }^{5}$ Like Duranti, I am aware of the problems inherent in a notion of intentionality in which intentions are univocal, pre-determined, a priori with respect to what happens in interaction. Granting that, in many cases, intentions are in the head of those who speak, there are cases in which intentionality is build collaboratively between the speaker and the hearer. The literary text is perhaps the best example. The electoral speech is a case in which the speaker's and the audiences' intention are not separate. The speaker speaks for the audience, and, thus, his intentionality ideally also mirrors the audience's intentionality. It's simply impossible to separate the speaker's and the audience's intentionality.
} 
vocalize them. In a sense, the speaker/author has to produce a text which conforms with, or even mirrors, the audience's intentionality. ${ }^{6}$ This is not a matter of hypocrisy or demagogy, but the obvious consequence of the commonplace that a politician must represent the audience's needs, feelings, worries, etc. On the other hand, the speaker/speech writer may use words that in some ways allow the audience to build its own intentionality. The audience, in other words, is allowed to construct the meaning of certain, deliberately vague expressions by adding their own understanding of the events that are alluded to. This is what Myers calls 'strategic vagueness' (Myers, 1996). When the main speaker says "We are tired of business as usual in Washington"7 (line 25), he presumably means "we are tired of the external influence of financial corporations on government", alluding to the fact that government is being dominated by the lobbies, an idea expressed later on in the text. ${ }^{8}$ Another interesting case is that in which meaning is determined not only by the speaker, but also by the hearers. Thus, when Obama talks about "big money in Washington", he presumably alludes to politicians that are part of the government: as Duranti (2006b) says, in the context of political discourse, "Washington" is a metonym for "the federal government", which includes elected and non-elected officials that are influenced by financial interests.

\subsection{Polyphony}

The polyphonic structure of Obama's electoral speech rests on the idea that the main speaker/author and the audience/ principal need to converge on the same meaning, by constructing it collaboratively. In fact, the main speaker, by including (narrative) inserts in his speech (lines 90-105), which represent the voices of his electorate, announces and emphasizes the level of constructed shared intentionality with his audience. The idea that a text incorporates many distinct voices is due to Bakhtin $(1981,1986)$ and will be very fruitful in the context of my analysis of Barack Obama's speech. What Obama does, in his speech, is to draw materials from previous (antecedent) discourses, thus instantiating what Kristeva (1986) calls 'horizontal intertextuality', a term indicating the ways in which texts and ways of talking refer to and build on other texts and discourses. As Bakhtin would say, Obama is "appropriating" discourses and voices which are not his own (Johnstone, 2002,139) and he is subordinating them to his own voice. Similarly Goodwin (2007) points out that very often, speakers talk by renting and recycling the words of others.

Whether the same process of intentionality co-construction by speaker and hearer occurs in ordinary speech is less clear. Surely English, like Italian, is a language in which there is a cultural bias in favour of the author/principal of the utterance determining the level of intentionality. It is, in a basic sense, the speaker's intention we have to reconstruct, especially in practical contexts where the speaker utters directives, questions, and other speech acts with a focus on action (and interaction). ${ }^{9}$ The challenge to this idea of the 'sovereign speaker' in literary theorizing is interesting, but does not seriously impugn the notion that in everyday interaction the speaker's intentionality is the focus of comprehension. There are, however, severely circumscribed contexts in which the hearer may help the speaker bring out what s/he means, by selecting verbal forms which reflect more accurately whatever thoughts $\mathrm{s} / \mathrm{he}$ wants to express. One of these contexts is the psychotherapeutic dialogue; another is the academic context of thesis/essay writing in which a tutor helps a student bring out his thoughts by selecting verbal forms more accurately expressing those same thoughts; a further context is that of the editorial process, in which an editor fulfills a 'maieutic' role in helping bring forth the writer's intended meaning. Additionally and most interestingly, the electoral speech is yet another of those contexts in which the main speaker/author and the audience/principal "come together" to construct meaning in a joint cooperative effort, in which the speaker is a sort of 'ventriloquist' (in Bakhtin's words), representing the audience by acting out their voices, and thus building electoral success on a correct representation of what the audience wants her to say. The audience, in its turn, expresses approval by filling out the deliberate pauses and uttering their consensus/disagreement with the intentions thus voiced; by doing this, they contribute to the co-construction of meaning along with the speaker/politician.

The deliberate pauses that a speaker makes are known to the audience as having to be filled by manifestations of approval/disapproval (cheering, chanting, etc.). True, such responses may be piloted, being prompted by the organizers who have blended in with the audience proper (as I indicated at the beginning of this section); however, the fact that the audience expresses a weaker approval in connection with certain parts of the speech (namely, the parts implying great sacrifices, possible mistakes, false beginnings, etc. See lines $39,83,84,85$ ) means that audience participation is real, that the audience is emotionally involved and acts instinctively and in accordance with their sentiments.

\subsection{Comparison with preaching discourse in Afro-American sermons}

Comparison with Afro-American preaching discourse may be of interest in further deepening these considerations. Actually, there is not much in terms of content in the speech by Barack Obama to induce us to categorize it as belonging to the

\footnotetext{
${ }^{6}$ This may look like a problematic notion. If the audience does not speak, but listens passively, then it is not completely clear that their intentionality is expressed or is in the air. However, there are at least two reasons for thinking that the audience's intentionality is in the air: the success of the electoral speech depends on the extent to which the speaker's words mirror what is in the mind of the audience; the audience participates and even by short responses can corroborate the words of the speaker and, thus, express intentions.

7 I show later that this is an echo from Martin Luther King's Jr.

8 The expression 'business as usual in Washington' has two implicit arguments - by ... - and - with .... - to be filled inferentially. The first slot is filled by 'politicians' and the second slot is filled by 'businessmen'.

${ }^{9}$ As Goodwin says, the case of reported speech is admittedly an exception.
} 
tradition of Afro-American preaching discourse. In fact, Obama is very careful to say that religious differences should not affect his political action. ${ }^{10}$ Yet, we have reasons to think that Barack Obama has been influenced by Afro-American preaching discourse. One may suggest that it is the concepts which Barack Obama is making reference to - and the concepts, one might argue, have a universal appeal - that may have originated in the speech of a black men, but then ascended to universal value by a universal acquiescence to the ideas originally voiced.

I would like to propose that it is not only concepts and ideals that Barack Obama appropriates and ventriloquizes in his speech, but that he also appropriates the tradition of Afro-American preaching discourse. Wharry (2003), in her most interesting article about Afro-American sermons, points out that such sermons rely on the presupposition that the audience should participate by uttering responses. This ties in very well with Bakhtin's notion of polyphony, in that multiple voices can be heard as giving support to an idea unit. It also ties in with Goffman's notion of footing, in that the preacher acts in his capacity as animator and the audience acts in his capacity as principal. The call-response technique is typical of this type of sermons. This technique supports the idea that, in interaction, meaning is being co-constructed, being the responsibility both of the speaker and of the hearer. The response (usually of a choral type) can express agreement or disagreement. Wharry explicitly says that the lack of a response is not heard as the indication that the audience is listening, but as an indication of disagreement. This is what happens in Obama's speech too: the audience participates saying "Yes" or "No" and when the responses are feeble, as after portions of text where the political leader reminds the audience of the sacrifices and suffering that awaits them, they may be interpreted as a failure to endorse Obama's words (lines 81-84). The call-response marker in Afro-American sermons is usually constituted by utterances such as "Say Allelujah", but Wharry also acknowledges that intonation and increase in volume play a role. The dialogic structure of Obama's speech serves to unify the speaker and the audience in the same way as it serves to unify the preacher and the audience in a religious Afro-American congregation. The speech should give the appearance of being constructed jointly by the speaker and the audience. So, in this sense we could say that Obama's speech parallels at least one feature of Afro-American discourse.

Another characteristic of Obama's speech that parallels a feature of Afro-American discourse is its rhythmic structure rhythm is more fundamental than grammar, and at many points we have the impression that rhythm prevails over grammaticality - the exigency of issuing a syntactically elegant discourse. Rhythm is achieved by devices such as repetition, volume increase, speed, etc. ${ }^{11}$

Another characteristic that Obama's speech shares with the Afro-American religious tradition is that it gives the impression of not being a written discourse. It gives the impression of being a mixture of parts which have been written and parts which have been created at the moment. The fact that he often recycles parts of previous speeches corroborates this impression. He gives the impression that his speech is sensitive and responds to the occasion and to the audience he faces.

Another characteristic of Afro-American sermons is that the preacher moves continually from the abstract to the concrete (and vice versa) (Davis, 1987). This is exactly what Obama does.

According to Davis (1987), there is in religious sermons a structure according to which the preacher initially says that he received ideas from God (this point in the structure is called 'elevation'); immediately after this point, his/her style becomes heightened and takes on a chant-like character. Obama, who does not utter a religious speech, surely cannot use this 'elevation' unit; after all, he does not claim to be inspired by God. Yet, it is natural to analyse what he says immediately following the greetings as a unit paralleling the 'elevation', on the basis of contextualization cues provided by intertextuality (Gumperz, 2003, 222). It is interesting to note that Obama somehow transforms the Afro-American religious tradition. It is enough to look at the incipit of his speech to say that he does so. After the greetings section, there is something like an 'elevation' section. He says:

Well over two weeks ago/ we saw the people of Iowa/ proclaim that our time for change has come

(lines 9-10)

His style shifts after what I call the transformed 'elevation' unit. To start with, the style is not excited, as when he greets the crowd and gives thanks to a number of people. But from that moment on, his style becomes heightened and takes on a chantlike cadence. It is like saying that he takes his inspiration from the people he aims to represent. There is surely a shift in footing here, exactly as there is one in the 'elevation' unit in Afro-American religious speeches: the speaker becomes an 'animator' of someone's else (important) voice (in the same way as the priest becomes the animator of God's voice).

The last characteristic of Obama's speech that closely resembles Afro-American sermons is the ending. The ending is left open-ended (Davis, 1987). On a first view of the video of Obama's South Carolina's speech, I was dissatisfied with its ending, I instinctively felt that there was no ending device, the end came abruptly without an effort to signal that it was upcoming (I even thought that I had seen only a fragment of the video). After all, the speech finishes with the words:

we will respond with that timeless creed that sums up the spirit of the American people in three simple words / "Yes we can" (lines 137-139)

If there is an indication that the speech is over that comes from "sums up the spirit" (after all a conclusion needs to sum up a speech); and the final utterance is pretty open-ended: "Yes, we can" (we can do what?). The utterance lends itself to an infinity of meanings.

\footnotetext{
${ }^{10}$ However, an article in Time February 18, 2008 speaks of Obama's messianism, referring to a sentence Obama uttered in the Super Tuesday speech: "We are the ones we've been waiting for".

11 Repetition has been shown by Atkinson (1984) to be involved in techniques for eliciting applause in political speeches.
} 


\subsection{Goodwin and the co-construction of meaning}

Interestingly, what happens in this electoral speech is similar, in structural terms, to the situation described by Goodwin (2007), in which a man whose speech has been impaired due to a severe stroke, can communicate by using his daughters' speech, by merely vocalizing brief responses such as "yes" and "no". Goodwin asks himself how a person who does not utter any speech can be an author or a principal (in Goffman's terms)? The answer is that the communicative situation is responsible (at least in part) for the shifting conventional identification between the animator and the author/principal. In the same way that an aphasic person can rely on his daughters to issue the speech he would like to issue, the crowd around a political speaker relies on the speaker to issue the speech they would like to issue. The relationship between the principal and the animator is not one of telepathy, but one of rationally guessing what kind of issues and attitudes the represented person would like to have addressed. The political leader has to guess what is of importance to her electorate, and her success is based on that of his rational guesses. She will be successful in representing an electorate only if she is successful in addressing the kind of issues that matter to them and is able to express their attitude to them. In slogan form, to win over the electorate, you must represent the complex articulation of the electorate; and most importantly, you have to speak using the electorate's words, thus showing that you really know what the their plights are, that you belong to them. The politician has a duty to represent her electorate. She must not just speak with the words of the electorate in order to obtain an electoral victory but she will be held responsible for the position she has taken. This notion of 'representing the electorate' is taken very seriously in Anglo-American countries, where the represented often write letters to their representatives in order to speak of a certain problem and where politicians often reply in writing to the letters they receive. The notion of representing another person is taken very seriously by a responsible politician, and it is this tradition which Barack Obama wants to revive and reinvigorate.

\subsection{Ventriloquizing}

In this section I investigate how Barack Obama uses ordinary stories in order to support his ideas. What he does is to give voice to a number of people through his narrations. We find both supportive voices and antagonistic voices.

\subsubsection{Ventriloquizing (supportive voices)}

Towards the end of his speech, Barack Obama introduces some voices he has heard (he actually refers to "the voices we carry on from South Carolina", implying that he has stopped to listen to these voices). He does what Goodwin (2007) calls putting certain persons on stage as characters, animating them as figures, as in the extract corresponding to lines 90-105.

By introducing the voices he has heard in South Carolina, Obama gives the impression that he is in touch with reality, but he also makes the audience feel that they are listening to real, authentic voices. What does the trick is the framing device "Theirs are the stories and voices we carry on from South Carolina" (line 90). This framing device has a prospective function in that it signals to the hearers what the next textual unit is about: what follows is not just one story ${ }^{12}$ but a series of (connected) stories and voices. The stories are not just there for mere narration, but they also afford the politician a chance to interpret them. In the first story, he says "That's what she is looking for" (line 93); in the second story, he says "she needs us to reform the education system" (line 95); in the third story, he says "he needs us to stop giving tax breaks to companies that ship our jobs overseas" (line 99); in the fourth and fifth stories (which are about the same topic), he says "they need us to come together and put an end to a war that should have never been authorized" (lines 105-106). In addition to forming a moral conclusion for each of his story, he moves on to a global conclusion to the summation of these stories:

So understand this South Carolina / the choice in this election is not between regions / or religions / or genders (Right) / it's not about rich vs poor (Right) / young vs old (Right) / and it is not about Black vs white (Yeah applause we want change 6) / This election is about the past vs the future. (Lines 107-108)

It is interesting to note that, while the local moral conclusions for each of these stories rely on some kind of descriptive generalization which could belong either to the main speaker or to the voice reported, at this point of the speech Obama moves on to a global moral conclusion that contains an injunction: "So understand this". This is at the same time a framing expression, embracing in its scope all of the previous stories. Hence, Obama's "So" does not connect with the last story in the series or with a particular one, but with the whole set of stories. Obama's use of a framing device such as "There are stories and voices we carry on from South Carolina" indicates the scope of the "So" in this context as a typical inferential connective: one idea is the consequence of another, such that we have to accept the former because of the earlier occurrence of the latter (Schiffrin, 1988); in contrast, its status as an inferential marker usually associated with orders/injunctions is less clear. Still, the injunction here sounds as a kind of categorical imperative: one must arrive at the conclusion $x$, given the evidence $y$, and in particular, one's understanding is involved in passing from $y$ to $x$. The imperative is a syntactic category associated with

\footnotetext{
12 A story is a narration unit which has a certain canonical structure, such as 'orientation' (introducing and identifying the participants in the action: the time, the place and the initial behavior); 'complication' (the arising of a major problem), 'resolution' (resolution of a major problem), 'coda' (The end of a narrative is frequently signaled by a Coda, a statement that returns the temporal setting to the present), 'evaluation' (in which one shows one's moral attitude to the events narrated).
} 
the speaker's voice. The fact that the imperative is being used to draw a conclusion from stories voiced through real people's stories is perhaps a signal that now the politician's voice is making itself heard, summing up and representing the chorus of voices heard so far. The speech within the scope of 'so' presents different voices. The main speaker's voice comes immediately after the negatives, the negative sentences presumably vocalizing the voices of his opponents. As Labov (1972) says, negative constructions can serve to bracket important ideas.

\subsubsection{Ventriloquizing the opponents}

The speech does not only include the actual people's voices, but also gives room to the voices of political opponents. While the actual people's voices were associated with descriptive referring expressions (e.g. "The mother who can't get Medicaid to cover all the needs of her sick child" (lines 90-91), "The Maytag worker / who is now competing with his own teenager for seven dollars an hour at Wal-Mart" (lines 97-98), "that woman who told me that she hasn't been able to breathe since the day her nephew left for Iraq”, (lines 113-115), etc.), the opponents' voices are expressed using impersonal demonstrative pronouns (e.g. "There are those who will continue to tell us that we can't do this / that we can't have what we're looking for / that we can't have what we want (Yes, No) / that we are peddling false hopes" (lines 113-115). These are not real demonstrative pronouns as they can be replaced with nouns like 'people' (e.g. 'There are people who will continue to tell us...'); semantically, these demonstratives are more like indefinite pronouns ('someone'). In other words, the voices attributed to the opponents are anonymous as they are not associated with anyone in particular. They are not the voices of real people, but of 'lobbies', abstract collection of vested interests. To such anonymous voices, Obama replies by quoting real voices:

I think of that elderly woman / who sent me a contribution the other day / an envelope that had a money order for 3 dollars and one cent (Yeah applause 5) ${ }^{* *} /$ along with a verse of scripture tucked inside the envelope / so don't tell us change is impossible / that woman knows change is possible. (lines 117-121)

Then he again lends voice to his opponents:

when I hear the cynical talk that Black and white and Latinos can't join together and work together (line 121)

This voice, too, is anonymous (though qualified by a negative adjective). To this voice, Obama replies using a particular person's voice:

I think about that Republican woman who used to work for Strom Thurmond / who is now devoted to educating Inner City children/ and who went out into the streets of South Carolina / and knocked on doors for this campaign (Yeah)** / don't tell me we can't change (lines 126-128)

Then Obama adds his own voice, summing up the import of the ensemble of voices:

So don't tell me we can't change (lines 128-129).

This is an echo of the message implied by the woman who sent him a cheque for three dollars and one cent. There is a resonance between the people's voices and the main speaker's voice; one reflects the others, one amplifies the others. The overall effect is that of multiple echoes being produced, of multiple resonance. In the end, it is not even clear who echoes whom; compare, for example, this excerpt from Time, February 11th, 2008 (p. 36):

“(...) Obama is a fresh face. His opponents promise to fight, but Obama promises healing. His is the native tongue of possibility, which is the native tongue of the young. And if he happens to be light on details - well, what are details but the dull pieces of disassembled dreams? "I had a friend who told me this was impossible, quoting all these political science statistics at me to show that it's hopeless to try to organize students", says Michelle Stein, 20, ( ... ). "Now he says, 'You were right, I was wrong. Where do I sign up?"'

This author is quite right in identifying the language of possibility with the language of young people, so this somehow corroborates my view that Obama's speech encapsulates other people's voices and that it also creates further resonances, as people in their discussions echo this language. Perhaps we need to reflect more on the identification of the 'language of possibility' with the language of young people - suffice it for now to say that younger people use the language of (simple) conditionals, while elderly people speak the language of counterfactual conditionals. Elderly people may have a speculative interest in counterfactual conditionals, whereas young people have a practical interest in exploring a reasoning based on possibility: the simple conditional is at the basis of future decisions. Elderly people have made all their most important decisions, whereas the young still have to face decisions in the light of reasonings in which possibilities feature as crucial elements.

One further reason for identifying the language of possibility with the language of young people, is that young people are usually more likely to believe in change, in things happening, in a new world. The elderly people are more used to expecting things to behave in the way they always did. 
The overall effect of this technique is very theatrical. The politician acts out many voices: both those of his opponents and those of the people who support him. However, he puts together the stories told by the real people's voices by subordinating them to his own voice. This is very much like conversational storytelling, in which a narrator tells a story to support his moral conclusion, and then another storyteller tells his own story either to support that conclusion or to contradict it. It is well known that storytelling is closely linked to establishing social bonds and shared values, and to asserting membership in a group (Norrick, 1997, 199-220).

\subsection{On stories and rhetorical strategies}

According to Duranti (2006b), stories play an important role in connecting a political candidate emotionally to the people he addresses in public speech. ${ }^{13}$ In the actual situation, the question naturally arises in which group Obama wants to claim membership. Since the stories he tells are many and deal with socially distinct groups, in his speech he identifies with each respective social group. His electoral purposes are well served by narrating stories that allow him to identify with each social group; his hidden agenda is to persuade all social groups to vote for him. The electoral purpose is best served by providing narratives constructing an authentic account, that is, an account that resonates with the teller's understandings and sensibilities of what it was like to participate in the events being narrated (Ochs, 2007, 47). The stories Obama uses are actually ministories or minimal stories (to use a term by Johnstone, 2003). In terms of Labov and Waletzky (1967) they lack an abstract and a resolution, yet they display bits of orientation (setting, participants), an evaluation, and a coda (making connections with the present). The lack of resolution is rhetorically connected with the success of the electoral speech: the speaker offers to provide a resolution to such stories.

The whole speech event is theatrical, because the audience hosts some of the dramatis personae, the organizers of the event, who suggest to the crowd what to say, who elicit the crowd's cheering or chanting. But are the crowds themselves, the people participating in the theatrical event, dramatis personae as well? Much of what happens makes us come to this conclusion. The crowd is acting out a ritual: the chanting, the cheering, is not spontaneous but is part of a script. The crowd is the audience proper, but for repeated periods of time, they act as well. Hence, at times the crowd is no longer the audience, while the speaker's role shifts to that of being audience.

The convergence between the people's voice and the main speaker's voice makes the main speaker one with the voices he acts out. The main speaker represents himself as one who represents the people's voices. If it is the people's voices that are represented in this speech, then the audience and the speaker work together in the construction of meaning, just as the speaker constructs meaning on the basis of the people's voices. The audience is entitled to read into the speech a communicative intention that does not just reside in the head of the main speaker, but also in the heads of the individuals whose voices he recounts. The cheering, the chanting, the various occurrences of 'Yeah', 'Right', or 'No' (the latter in response to the anonymous voices of the political opponents), entitle the main speaker to claim identification with the audience; but if he is speaking on their behalf, then there is also identity in the intentions.

\section{Discussion}

In this paper, I considered the case of an electoral speech event in which, despite the fact that rhetoric is present, manipulation is kept at a minimum, as the speaker does not attempt to persuade the audience to come to his side, to accept his views, given that he presents his views as coming from the people. In Obama's speech, I analyzed the case in which a politician makes use of the people's voices in order to show that he correctly represents the needs and sentiments of his nation, thus being entitled to represent them as a political leader and to do what is good for them. The speech emerges not as something for which (only) Obama is responsible, but as something for which the people (in particular those attending the electoral speech) are responsible. Obama's success lies in the fact that he manages to persuade the audience that the speech does not come from him, but from their own voices. Here, electoral victory must be seen as success in representing the speaker as a person who impersonates the audience's needs and sentiments. Obama manages to project himself as a person who animates (in Goffman's sense) a speech for which not he, but the people are responsible. Electoral success is granted him because the people can consider themselves the principal (again, in the sense of Goffman): the persons, institutions, or collections of communities which are ultimately responsible for what is said in the speech.

What is going on here is a complex process, in which (following Duranti, 2006a) the speaker's meaning is a construction on the part of the audience as well. As Vološinov $(1973,86)$ says, "the word is a two-sided act. It is determined equally by whose word it is and for whom it is meant". In our case, the process of speaking is actually somewhat more complicated, in that by way of literary citations, Obama recycles parts of Martin Luther King's "I have a dream" speech (see Time, December 3, 2007, p. 21 below). The phenomenon described in this article resembles closely what Lauerbach (2006) calls voicing:

\footnotetext{
${ }^{13}$ However, Duranti considers stories of belonging in which a candidate narrates past experiences that connect him with the audience in order to show that that he is an ideal representative in so far as he has shared experiences with the audience.
} 
Representing the discourse of others functions as a device whereby speakers can distance themselves from what is being expressed, positioning themselves in a Bakhtinian dialogic universe of voices other than their own (White 2000). In Goffman's $(1974,1981)$ terms, a figure other than the speaker is being animated without the speaker being understood to be either the author of the words or to be responsible for them. This type of representing discourse will be called 'voicing' here (Lauerbach, 2006, 198-199).

In the present paper, I hope to have established a connection between the institution of the electoral speech and the notion of the participatory framework. In the electoral speech, a powerful transformation is effected: while speech in ordinary circumstances is associated with a speaker who is, at the same time, animator, author, and principal, in the electoral speech transcribed above we have witnessed how the role of principal may become uncoupled from the roles of animator and author. Somewhat surprisingly, in the context of the electoral speech, the audience has been attributed the role of principal, while the main speaker has been relegated to the role of animator/ author.

What happens in an electoral speech such as the one analyzed here can perhaps best be described in terms of Duranti's felicitous terminology of translocutionary act. A translocutionary act, according to Duranti, is an act whose pragmatic force is realized by transcending clausal, as well as individual speech act boundaries. Duranti (1991) writes:

The very notion of Translocutionary Act also tries to account for a view of linguistic communication as not simply consisting of a series of individual intentions that are realized through conventional linguistic acts (Searle, 1983), but as a complex activity that involves mutually constituted and sequentially sustained units that defy a characterization of meaning as primarily originated in the speaker's mind. What we would like to allow instead is for a definition of meaning as something existing between speakers (Vološinov, 1973).

I agree with Duranti and Brenneis (1986) that audiences are always in one way or the other co-authors, sometimes contributing to the construction of form, sometimes contributing to the determination of meaning. I also agree with Duranti (2006a) that the concept of intentionality is part of Western culture and that in some other cultures - like that of the Samoan people - mind-reading is not even attempted in the evaluation of action. According to Johnstone (2000:139), these ideas "have challenged the conventional view that speakers are naturally and completely in control of their utterances". However, contrary to this view, I find that political speeches are quite unique in this respect, because they create the expectation that the main speaker and the audience converge in their interpretation of the speech's meaning. The text of an electoral speech is a text in which the barriers between the speaker/author's and the audience/principal's intentionalities are corroded, and where convergence is implied (given the fact that the speaker/author interprets the sentiments of the audience and represents such sentiments in his speech); alternatively, the speech favours certain semantic slots where deliberately vague expressions are picked up in order to express exactly what the audience would like to express by them.

Duranti's ideas remind us of some original work by Mey (2001). However, when one reads Mey's ideas one has an outlook which coheres to a greater extent with the ideas I presented in this paper. What I did in this paper was to connect intertextuality with the communicative situation (or the speech event) saying that there is something inherent in certain speech events that brings out the possibility of animating the audience's words. When we read Mey (2001: 221), we see that he also connects the idea that languages uses are situated in specific communicative events with the idea that meaning is created by an interactional process in which speakers and hearers participate on equal footing.

My analysis of Barack Obama's South Carolina victory speech sustains Duranti's/Mey's notion that both the speaker and the hearers participate in the construction of meaning. First of all, it is the type of convention involved in the communicative event 'electoral speech' that effects the transformation required to see the connection of Obama's voice with the voice(s) of the audience. Second, Obama frequently prompts the audience to unite their voices with his. Third, there are many slots in the speech in which, due to lexical vagueness, the audience is invited to join the speaker and complete his authorial work. Fourth, Obama invokes or acts out voices that can be seen as representing the audience's voices, thus making it appear that the audience is the principal on behalf of whom he is seen to be speaking. No doubt the use of all these various techniques makes a strong case for the idea that meaning is projected as "something existing between speakers" (Vološinov, 1973).

\section{Conclusion}

Summing up, in this paper I have discussed the notions of footing and polyphony in order to make sense of what happens in a particular discourse. In particular I have shown that Barack Obama ventriloquizes the voices of ordinary people in order to support his campaign, while also incorporating the voices of his opponents which are marked stylistically as different (anonymous) from those of the people who support his ideas. The main idea of the paper is that Obama takes seriously the politician's role as representative (of the people) and expresses the voices he wants to represent in order to support his ideas about politics, in respect to which he presents himself as the animator, while giving ordinary people the role of principals. 
Appendix 1. Transcription of Barack Obama's South Carolina victory speech

The following transcription makes use of a few extra symbols.

** stands for overlapping speech.

/ stands for a segment differentiated from a previous speech segment through a deliberate pause. Such a pause allows Obama to take a breath or to elicit consensus (cheering, chanting, vocal agreement, etc.).

The numbers in bold (e.g. 10) indicate the length of the pauses (in terms of seconds) in which chanting, cheering, etc. occurs. In this transcription, I also use a special symbolism to indicate speech becoming slower or softer. When speech becomes softer, I use italics. When speech becomes slower, I underline it. (Compare that according to Tannen, 2007, a speaker can project a pause to invite a response from the recipient (in this case, the audience) by making her speech softer or slower). I use boldface (except for numbers) to indicate a conspicuous rise-fall intonation.

Below is my transcription of the communicative event.

Yes we can ${ }^{* *}$ Yes we can Yes we can Yes we can Yes we can Yes we can 6) Thank you. (Yes we can 5) (Yes we can)/ Thank you. ** (Yes we can 10)/

Thank you. Thank you everybody./

Thank you./ Thank you South Carolina / Thank you./ Thank you (Yeah 1) / Thank you South Carolina (Yeah) / Thank you to the rock of my life Michelle Obama / (Yeah 7) Thank you to Malia and Sasha (Natasha) Obama who haven't seen their daddy in a week (Yeah 8 / Thank you to Pete Skidmore (Yeah $\mathbf{1}$ ) ${ }^{* *}$ for his outstanding service to our country and being such a great supporter of this campaign ${ }^{* *}$ (Yeah 6) / Well over two weeks ago / we saw the people of lowa/ proclaim that our time for change has come (Yeah Yes we can) 5/ But there are those who doubted (No) / this country's desire for something new (No) / who said "Iowa was a fluke (No) $\mathbf{2}$ / not to be repeated again". (No) / Well tonight the cynics who believed that what began in the snows of Iowa was just an illusion ( No) / were told a different story by the good people of South Carolina (Yeah yes we can 16). After four / (Yes we can)/after four great contests / in every corner of this country / we have the most votes (Yeah) $\mathbf{2}$ / the most delegates (Yeah Yes we can 9)/ and the most diverse coalition of Americans_(Yeah)** that we've seen in a long long time ${ }^{* *}$ (Yeah we can change) $\mathbf{2 5}$ / There you can see it in the faces here tonight (Yeah) $\mathbf{3}$ / they are young and old (yeah 3) / rich and poor (Yeah3) / they are black and white (Yeah 3) / Latino and Asian and Native American (Yeah) 6 / They are Democrats from Des Moines/ and independents from Concord / and yes some Republicans from rural Nevada (yeah) 3 / and we've got young people all across this country (Yeah) 8 / who have never had a reason to participate until now (Yeah) / and in nine days / in nine short days / nearly half of the nation/ will have the chance to join us in saying that we are tired of business as usual in Washington (Yeah) $\mathbf{4}^{* *} /$ we are hungry for change / and we are ready to believe again ** (Yeah) (we want change 8) / but if there is anything though that we have been reminded of / since Iowa / is that the kind of change we seek / will not come easy (yeah) $\mathbf{2}$ / now partly because we have fine candidates in this field fierce competitors who are worthy of our respect and admiration (Yeah) 5 / and as contentious as this campaign may get/ we have to remember that this is a contest for the Democratic nomination (Yeah) $\mathbf{2}$ / and that all of us share an abiding desire to end the disastrous policies of the current administration (Yeah) $\mathbf{7}$ / But there are real differences between the candidates (Yeah) 2 / We are looking for more than just a change of party in the White House (Yeah) $\mathbf{2}$ / We're looking to fundamentally change the status quo in Washington (Yeah) $\mathbf{5}$ / It's a status quo that extends beyond any particular party and right now that status quo is fighting back with everything its got (yeah) $\mathbf{2}$ / with the same old tactics that divide us and distract us from solving the problems people face (Yeah) $\mathbf{1}$ / whether those problems are health care the folks can't afford or the mortgages they cannot pay (Yeah) 2 So this will not be easy (no) 1 / Make no mistake about what we are up against (yes) 1 / We are up against the belief that it's alright for lobbyists to dominate our government (no) / that they are just part of the system in Washington (no)/ But we know that the undue influence of lobbyists is part of the problem/and this election is our chance to say (Yeah) $\mathbf{5}^{* *}$ that we are not going to let them stand in our way/ anymore ${ }^{* *}$ (No) 8 / We are up against the conventional thinking that says your ability to lead as president comes from longevity in Washington / or proximity to the White House / but we know that real leadership is about candor / and judgement / and the ability to rally Americans from all walks of life around a common purpose (Yea) $3^{* *} /$ a higher purpose $e^{* *}$ (yeah) / we are up against decades of bitter partisanship that caused politicians to demonize their opponents instead of coming together (Yeah) $\mathbf{2}$ / to make college affordable (Yeah) $\mathbf{2}$ / or energy cleaner (Yeah) $\mathbf{2}$ / It's a kind of partisanship where you are not even allowed to say that a Republican had an idea (Yeah) $\mathbf{2}$ / even if it's one you never agreed with (Yeah) 2. That's the kind of politics that is bad for our party / It is bad for our country/ and this (Yeah) is our chance to end it once and for all (Yeah) $\mathbf{1 0}$ / We are up against the idea that it's acceptable to say anything and do anything to win an election (No) / But we know that this is exactly what's wrong with our politics / This is why people don't believe what their leaders say anymore / This is why they tune out / And this election is our chance to give the American people a reason to believe again (Yeah) $\mathbf{5}$ / But let me say this South Carolina / what we have seen in these last weeks is that we're also up against forces that are not the fault of any one campaign / but feed the habits that prevent us from being who we want be as a nation (Yeah) 2. That's a politics that uses religion as a wedge (yeah) 2 / and patriotism as a bludgeon (Yeah) 2 / a politics that tells us that we have to think, act, and even vote within the confines of the categories that supposedly define us (Yeah) 3 /The assumption that young people are apathetic (No) 6 / The assumption that Republicans won't cross over (No) 3 / The assumption that the wealthy care nothing for the poor (No) 2 / and that the poor don't vote (No) 2 /The assumption that African-Americans can't support the white candidate/ whites can't support 
Afro-American candidates / that Blacks and Latinos cannot come together/ We're here tonight to say that this is not the America we believe in (Yeah, Yes we can) 15 / I did not travel around this state over the last year and see a white South Carolina / or a black South Carolina / I saw South Carolina (Yeah) 6 / I saw crumbling schools/ that are stealing the future of black children and white children alike (Yeah) 3 / I saw shuttered mills and homes for sale that once belonged to Americans from all walks of life / And many women of every colour and creed/ who serve together and fight together and bleed together under the same proud flag / I saw what America is and I believe in what this country can be (Yah) 2 / That is the country I see / ${ }^{* *}$. That is the country you see / Yeah But now it is up to us to help the entire nation embrace this vision ${ }^{* *}$ (Yeah) (we can change) 20 Because in the end we are not up just against the ingrained and destructive habits of Washington/ We are also struggling with our own doubts / our own fears / Our own cynicism / the change we seek has always required great struggle and great sacrifice (Yeah) 1 / and so this is a battle in our own hearts and minds / about what kind of country we want / and how hard we're willing to work for it (Yeah) / So let me remind you tonight / that change will not be easy / change will take time (Yeah) 1 /There will be setbacks (Yeah) $1 /$ and false starts (Yeah) 1 / and sometimes we'll make mistakes (yeah) $\mathbf{1}$ / but as hard as it may seem we cannot lose hope (Yeah) 1 because there are people all across this great nation/ who are counting on us (Yeah) $\mathbf{2}$ / who can't afford another four years without health care ** (Yeah applause) 5 / They can't afford another 4 years without good schools (Yeah) $\mathbf{3}$ / They can't afford another 4 years without decent wages (Yeah) $\mathbf{3}$ / because our leaders couldn't come together and get it done ${ }^{* *}$ (yeah) 3 . Theirs are the stories and voices we carry on from South Carolina/ The mother who can't get Medicaid to cover all the needs of her sick child / she needs us to pass a health care plan that cuts costs (yeah) ${ }^{* *} /$ and makes health care available and affordable/ for every single American / That's what she's looking for ${ }^{* *}(\overline{Y e a h}) 7$ / The teacher who works another shift at Dunkin Donuts after school/ just to make ends meet / she needs us to reform our education system (Yeah) / so that she gets better pay and more support (Yeah)/ and her students get the resources that they need to achieve their dreams (Yeah) 3 The Maytag worker / who's now competing with his own teenager for a seven-dollar-an-hour job at the local WalMart because the factory he gave his life to shut its doors/ he needs us to stop giving tax breaks to companies that ship our jobs overseas (Yeah)** $\mathbf{6}$ and start putting them in the pockets of working Americans who deserve it ** (Yeah)/ and put it in the pockets of struggling home owners who are having a tough time / and looking after seniors who should retire with dignity and respect (yeah) 3 / that woman who told me that she hasn't been able to breathe / since the day her nephew left for Iraq/ or the soldier who doesn't know his child because he's on his_third or fourth or even_fifth tour of duty (Yeah) 2 / they need us to come together and put an end to a war that should have never been authorized (yeah) ** / and should have never been waged **(Yeah applause we can change 13 / So understand this South Carolina/ the choice in this election is not between regions / or religions / or genders (right) / it's not about rich vs poor (Right) / young vs old (Right)/ and it is not about black vs white (Yeah applause Yes we can) 6 / This election is about the past vs the future (Yeah applause) 5 It's about whether we settle for the same divisions and the distractions and dramas that passes for politics today Or whether we reach for a politics of common sense/ and innovation / a politics of shared sacrifice / and shared prosperity / There are those who will continue to tell us that we can't do this / that we can't have what we're looking for / that we can't have what we want (yes, no) / that we are peddling false hopes / but here's what I know/I know that when people say we can't overcome all the big money and influence in Washington (Yeah) 2 / I think of that elderly woman/ who sent me a contribution the other day/ an envelope that had a money order for three dollars and one cent (Yeah applause) $5^{* *} /$ along with a verse of scripture tucked inside the envelope / "so don't tell us change is impossible"/ that woman knows change is possible ** (Yeah)/ when I hear the cynical talk that blacks and whites and latinos can't join together and work together / I am reminded of latino brothers and sisters/ I organized with / and stood with / and fought with / side by side/ for jobs and justice on the streets of Chicago/ So don't tell us change (Yeah) ${ }^{* *}$ can't happen **(Yeah applause We can change) 11 / When I hear that we'll never overcome the racial divide in our politics / I think about that republican woman who used to work for Strom Thurmond / who is now devoted to educating Inner City children / and who went out into the streets of South Carolina / and knocked on doors for this campaign (Yeah)** / don't tell me we can't change (Yes we can) 5 / Yes we can / Yes we can / Yes we can change/ **(Yes we can) 7 Yes we can heal this nation (Yeah)3 / Yes we can seize our future (yeah)3 / and as we leave this great state / with a new wind in our backs (Yeah) 3 / and we take this journey across this great country (Yeah) 2 / a country we love with the message we've carried from the plains of Iowa / to the hills of New Hampshire (Yeah) 3, from the Nevada Desert to the South Carolina coast (Yeah) 3 / the same message we had / when we were up / and when we were down (Yeah) $3^{* *} /$ that out of many we are one (Yeah) 3 / That while we breathe we will hope (Yeah) ${ }^{* *} 3$ And where we are met with cynicism and doubt and fear and those who tell us that we can't, we will respond with that timeless creed that sums up the spirit of the American people in three simple words/ "Yes we can" **(Yes we can)/Thank you South Carolina (broken off here... ) (Yes we can)/ Thanks / I love

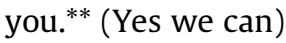

\section{Appendix 2}

When I read, in an article in Time (December 3rd, 2007, p. 21), that Barack Obama's speeches reverberate with the voice of Martin Luther King Jr., asking us to reflect on "the fierce urgency of now", I read the "I have a dream" speech to see to what extent King's style (or voice) is present in Obama's South Carolina's speech. Not surprisingly a number of echoes could be found (for example, Barack Obama repeats Martin Luther King's expression 'business as usual'). In addition, there are borrowed metaphors, such as the wind as a symbol of change (King's "the whirlwinds of revolt", compare Obama's "with a new wind in our back"); there are concepts Obama repeats, e.g., when he says that people should begin to believe in politics again (compare King: "We cannot be satisfied as long as a Negro in Mississipi cannot vote and a Negro in New York believes 
he has nothing for which to vote"); like Martin Luther King, Obama lists geographical names as a way of suggesting spiritual unity (see also Wharry, 2003 on this notion); also, he uses stylistic effects such as long lists of coordinated structures, with contrasting modifiers (Obama:'s "I did not travel around this state over the last year and see a white South Carolina / or a black South Carolina / I saw South Carolina” is reminiscent of M.L. King's “One day right there in Alabama little black boys and black girls will be able to join hands with little white boys and white girls as sisters and brothers"). Obama's usage of idealistic enthusiasm ("that timeless creed") is parallel to King's ("with this faith").

\section{References}

Atkinson, Max, 1984. Public speaking and audience responses. In: Atkinson, M., Heritage, J. (Eds.), Structures of Social Action. Cambridge University Press, Cambridge, pp. 370-409.

Bakhtin, Mikhail Mikhailovich, 1981. The Dialogic Imagination. Trans. C. Emerson, M. Holquist. University of Texas Press, Austin.

Bakhtin, Mikhail Mikhailovich, 1986. Speech Genres and Other Late Essays. Trans. V.W. McGee. University of Texas Press, Austin.

Bauman, Richard, Sherzer, Joel (Eds.), 1974. Explorations in the Ethnography of Speaking. Cambridge University Press, Cambridge.

Capone, Alessandro, 2005. Pragmemes. Journal of Pragmatics 37, 1355-1371.

Capone, Alessandro, forthcoming. Default Semantics and the Architecture of the Mind. Journal of Pragmatics.

Davis, Gerald, 1987. I Got the Word in Me and I Can Sing It, You Know. University of Pennsylvania Press, Philadelphia.

Dennett, Daniel, 1991. Consciousness Explained. Penguin, London.

Duranti, Alessandro, Brenneis, Donald, 1986. The audience as co-author. Special issue of Text 6/3, $239-247$.

Duranti, Alessandro, 1991. Four properties of speech-in-interaction and the notion of translocutionary Act. In: Verschueren, J. (Ed.), Pragmatics at Issue: Selected Papers from the International Pragmatics Conference, Antwerp, August 17-22, 1987, vol. I. Benjamins, Amsterdam, pp. 133-150.

Duranti, Alessandro, 2006a. The social ontology of intentions. Discourse Studies 8/1, 31-40.

Duranti, Alessandro, 2006b. Narrating the political self in a campaign for U.S. Congress. Language in Society $35,467-497$.

Goffman, Erving, 1974. Frame Analysis. An Essay in the Organization of Experience. Northeastern Press, Boston.

Goffman, Erving, 1981. Forms of Talk. University of Pennsylvania Press, Philadelphia.

Goffman, Erving, 2007. Footing. In: Monaghan, L., Goodwin, J. (Eds.), Voicing: Reported Speech and Footing in Conversation. Cambridge University Press, Cambridge, pp. 396-400.

Goodwin, Charles, 2007. Interactive footing. In: Holt, E., Clift, E. (Eds.), Voicing: Reported Speech and Footing in Conversation. Cambridge University Press, Cambridge, pp. 16-46.

Gumperz, John, 2003. Interactional sociolinguistics. In: Schiffrin, D., Tannen, D., Hamilton, H. (Eds.), The Handbook of Discourse Analysis. Blackwell, Oxford, pp. 215-228.

Hymes, Dell, 1964. Introduction: towards ethnographies of communication. American Anthropologist LXVI/6, $13-35$.

Johnnstone, Barbara, 2000. The individual voice in language. Annual Review of Anthropology 29.

Johnstone, Barbara, 2002. Discourse Analysis. Blackwell, Oxford.

Johnstone, Barbara, 2003. Discourse analysis and narrative. In: Schiffrin, D., Tannen, D., Hamilton, H. (Eds.), The Handbook of Discourse Analysis. Blackwell, Oxford, pp. 635-649.

Kochman, Thomas, 1981. Black and White Styles in Conflict. University of Chicago Press, Chicago.

Kristeva, Julia, 1986. In: Moi, T. (Ed.), The Kristeva Reader. Blackwell, Oxford.

Labov, William, 1972. Language in the Inner City. University of Pennsylvania Press, Philadelphia, pp. $354-405$.

Labov, William, Waletzky, Joshua, 1967. Narrative analysis: oral versions of personal experience. In: Helm, J. (Ed.), Essays on the Verbal and Visual Arts. University of Washington Press, Seattle, pp. 12-44.

Lauerbach, Gerda, 2006. Discourse representation in political interviews: the construction of identities and relations through voicing and ventriloquizing. Journal of Pragmatics 38, 196-215.

Mey, Jacob, 2001. Pragmatics. An Introduction. Blackwell, Oxford.

Myers, Greg, 1996. Strategic vagueness in academic writing. In: Ventola, E., Mauranen, A. (Eds.), Academic Writing: Intercultural and Textual Issues. Benjamins, Amsterdam, pp. 3-17.

Norrick, Neal, 1997. Twice-told tales: collaborative narration of familiar stories. Language in Society 26, 199-220.

Ochs, Elinor, 2007. Narrative lessons. In: Monaghan, L., Goodwin, J. (Eds.), A Cultural Approach to Interpersonal Communication. Blackwell, Oxford, pp. 41-49. Perrot, Laurent, 2000. La rhétorique dans l'antiquité. Librairie Générale Français, Paris.

Searle, John, 1983. Intentionality. Cambridge University Press, Cambridge.

Schiffrin, Deborah, 1988. Discourse Markers. Blackwell, Oxford.

Tannen, Deborah, 2007. Conversational signals and devices. In: Monaghan, L., Goodwin, J. (Eds.), A Cultural Approach to Interpersonal Communication. Blackwell, Oxford, pp. 150-160.

Van Dijk, Teun, 2003. Critical discourse analysis. In: Schiffrin, D., Tannen, D., Hamilton, H. (Eds.), The Handbook of Discourse Analysis. Blackwell, Oxford, pp. $398-415$.

Vološinov, Valentin Nikolaevich, 1973. Marxism and the Philosophy of Language. Harvard University Press, Cambridge, MA.

Wharry, Cheryl, 2003. Amen and Hallelujah preaching: discourse functions in African American sermons. Language in Society $32,203-225$.

Dr Alessandro Capone carries out his research at the University of Palermo. He has a doctorate from the University of Oxford. He wrote extensively on pragmatics. He is now co-editing a book on 'de se' attitudes to be published by CSLI, Stanford. He has edited 'Perspectives on language use and pragmatics. A volume in memory of Sorin Stati' (Lincom, Muenchen, 2010). 